\title{
What Is Culture of College/School/Department ${ }^{*}$
}

\author{
WANG Lian-sen \\ Shandong Women's University, Jinan, China; \\ Shandong University, Jinan, China
}

\begin{abstract}
College culture is university subculture, and a unique organization culture form created, discovered, and developed from long-term teaching management practice, generally accepted, recognized, and followed by teachers and students of college/school/department. College culture can be concluded in "academic culture," "administrative culture," "association culture" based on "functional form of culture," or "teacher culture," "student culture," and "administer culture," according to "the subject form of culture." Except "classification," it can be divided into three levels of "material," "institution," and "spirit"; or four levels of "material," "institution," "behavior," and "spirit." College culture, compared to campus culture, is a subculture, but has its independence and dissimilarity. At management aspects, college culture has directing function, cohere function, constrain function, incentive function, coordination function, and assimilation function. At social aspects, college culture has radiation function and image-building function. At education aspects, college culture can have an impact on students' professional qualities, moral character, and personality growth. Cultural construction should be conducted adhering to the principle of "overarching and guiding," "materialization and enrichment," and "specificity and characteristic."
\end{abstract}

Keywords: college culture, school culture, department culture, campus culture, university culture

\section{Introduction}

Since the 1970s, a wave of culture studies themed "organizational culture" ("corporate culture"), "campus culture," "university culture," etc. come one after another in rapid succession. Along with beginning to expand the autonomy of running universities since the mid-1980s, especially the continuous reform of "college system" and implementation of two-level (university and college) management system since the enlarged enrollment and amalgamation of universities in the 1990s, they stimulated people's concern and interest on "college culture" (referring to college culture, school culture, and department culture).

\section{Connotation of College/School/Department Culture}

According to the general understanding of "university culture," broadly speaking, college culture is the sum of material wealth and spiritual wealth created by the college with its own characteristic. In a narrow sense, college culture refers to a organization's administrative characteristics, values, interpersonal relationships, traditions, norms, spirit and corresponding teaching, scientific research, and cultural and sports activities (Gao,

\footnotetext{
* Acknowledgement: This research was financially supported by Humanities and Social Science Research Project of Ministry of Education (Grant No. 15YJA880069), Research Project of China Academic Degrees \& Graduate Education Society (Grant No. 2015Y11), and Independent Innovation Foundation of Shandong University (Grant No. IFW12116).

WANG Lian-sen, Ph.D., associate professor, School of Tourism, Shandong Women's University; researcher, Institute of Higher Education, Shandong Women's University; researcher, Research Center for Higher Education, Shandong University.
} 
2001, p. 96). College culture is university subculture, and a unique organization culture form created, discovered, and developed from long-term teaching management practice, taking all faculties, teachers and students of college/school/department as main roles and knowledge and profession (academy) as basis... generally accepted, recognized, and followed by college/school/department teachers and students... it is embodied in the teaching activities, student work and a variety of affair management, and reflected through spiritual outlook, way of thinking and behavior patterns (Bian \& Yue, 2009, p. 66). As secondary academic institution in or directly under universities - college (school and department) was established based on one or several disciplines/professional(s), members are "more similar by practice" and interact more, and its culture is more "deformability." Small and concentrate organization make the culture more "controllable." Therefore, college culture is easy to be "created," "shaped," and "felt," and then attracts people's attention and thinking, especially the "insiders"- university faculty staff and students in college/school/department.

\section{Constitution of College/School/Department Culture}

Although college culture is "university subculture," but it is almost equivalent to campus culture in rich content and complexity (Wang \& Wang, 2006, p. 39), because it is also a cultural group including professional culture, academic culture, teacher culture, student culture as well as management culture, office culture, etc. (Bian, 2008). If a clear classification basis is needed, college culture can be concluded in "academic culture," "administrative culture," "association culture" based on "functional form of culture," or "teacher culture," "student culture," and "administer culture," according to the subject form of culture (Li, 2012, pp. 12-13).

Except "classification," college culture can also been leveled according to components status and relations to display its unique "onion" structure - from outside to inside, it can be divided into three levels of "material," "institution," and "spirit" (Gao, 2001, pp. 97-98), or four levels of "material," "institution," "behavior," and "spirit" (Chen, Bi, \& Wang, 2010, p. 121). Regardless of classification method, "spirit is always the core of college culture" (Gao, 2001, p. 98), because spirit culture .... "embodies the value pursuit and rational cognition of the college overall development" (Chen \& Li, 2010, p. 111), "dominates the formation of college tradition and trend of college development, and directly determines the college management mode, behavioral pattern, interpersonal relationships, behavior criterion, and style and feature" (Zhao, Wang, \& Zhang, 2011, p. 106).

\section{Nature of College/School/Department Culture}

College culture, compared to campus culture, is a subculture, but has its independence and dissimilarity. Independence comes from college's relative independence from university currently; dissimilarity comes from college's academic features, rather than simple and homogeneous chunk (Wang \& Wang, 2006, p. 39). As "a distinctive culture based on specific discipline or profession reflected in the college" (Wang \& Wang, 2006, p. 39), college culture has the features of "discipline, localization, openness, permeability" (Wang \& Wang, 2006, p. 39), as well as "dependence and penetrability," "diversity and systematization," "academic and morality education," etc. (Bian \& Yue, 2009, pp. 67-68).

As a "distinctive culture," also known as "individual culture" (Li, 2012, pp. 14-16), college culture not only has pros and cons - good college culture has six obvious signs: clear college sprit, shared values, good work and study environment, management institutions being recognized and abided by the crowd of college, harmonious interpersonal relationship, and all staff and students full of vitality and enthusiasm (Chen, Bi, \& Wang, 2010, p. 121), but also "has superficial and profound culture, superficial culture has no big culture 
strength like a flash of light, while profound culture is like wine cellars for years, sweet and long aftertaste" (Tang, 2013, p. 163).

\section{The Relationship Between College Culture and Campus Culture, University Culture}

Compared with college culture, campus culture is more comprehensive which is created from integration and blending of different cultural characteristics of disciplines, professionals, colleges/schools/departments, units, more representing a general culture in the university, therefore, they are in a relationship as the universal to the particular (Cai, 2006). Furthermore, "campus culture is the foundation and background of college culture" (Wang \& Wang, 2006, p. 40); "college culture is a microcosm and specific mapping of campus culture" (Cai, 2006), which "integrated in campus culture" (Bian, 2008, pp. 17-18), "and an integral part of university campus culture" (Chen, Bi, \& Wang, 2010, p. 121), but "has a certain independence to displays its specific characteristics on the basis of inheriting and absorbing up campus culture" (Cai, 2006). This close relationship led to a "mutually beneficial" effect - campus culture can maintain the stability of college culture, and college culture can increase the diversity of campus culture (Chen, Bi, \& Wang, 2010, p. 121), which "constitutes a unique campus culture ecosphere... universal and individual college culture makes the whole campus culture more full, rich and vibrant" (Ma, 2013, p. 86).

Based on the above analysis, it is not difficult to understand that on the one hand, university culture, at macro level, guide the development direction of college culture, on the other hand, various college culture, based on disciplines diversity, influence, and contribute to university culture (Chen \& Li, 2010, p. 111). It should be emphasized that college culture is an integral and important part of university culture, is a major force in forming a university culture style, college cultural construction influences the process, direction, vitality, and effectiveness of university culture (Ouyang, 2014, p. 246), "doing well in college cultural construction is to promote, expand and substantiate university culture" (Zhao, Wang, \& Zhang, 2011, p. 105).

In short, the university cultural construction is a systematic project, secondary college and university is in a relationship as the part to the whole, secondary platform to first platform, if there is no interaction and cooperation between the two platforms, university cultural construction will be fragmented (Fei, 2013, p. 140).

\section{Function of College/School/Department Culture}

\section{Management Aspects}

Directing function. College culture, as an organization culture, can direct the value and behavior of whole organization and each member to meet the need of organization development (Gao, 2001, p. 96).

Cohere function. Good college culture can promote the formation of common ideals and beliefs, psychological characteristics, ethical standards and values among teachers and students, and stimulate college members' identity and pride to college goals and standards, and thus, increase cohesion and consolidate internal power (Zhu, 2012, p. 48).

Constrain function. As organizational culture, college culture has a binding and regulatory effect on the ideas, psychology and behavior of each member. This is a kind of soft constraint, which means group psychological pressure and self-control caused by organization cultural atmosphere that makes individual behavior conformity (Gao, 2001, p. 96).

Incentive function. In addition to constrain, college culture can from the core idea of respect for human, make the faculty to feel enthusiastic and energetic from the heart through inner guidance, and consciously work 
for the organization (Gao, 2001, p. 96). Of course, the incentive is directional, which can be positive or negative, thus, college culture can be classified into positive incentive culture, insufficient incentive culture, and negative incentive culture (Yang \& Guo, 2013, pp. 64-65).

Coordination function. College culture can automatically adjust the organization members' attitude and actions through harmonious atmosphere, and gradually becomes the main culture of the organization through psychological identity to the cultural atmosphere, turning the common goal into members' conscious actions, achieving the unity of personal goals with organizational goals at a higher level, so that the group can have the greatest synergy. Meanwhile, it can continuously permeate and internalize personal values through common values, enabling the organization to automatically generate a set of self-regulation mechanisms, and manipulate the management behavior and practice activities of the organization by "invisible hand" (Li, Shen, \& Ren, 2013, p. 59).

Assimilation function. Along with coordination function, college culture also influences any member of the organization by organization values, behavior style, moral criterion, and other ideology systems, to make them assimilate to the organization culture in the above aspects. Assimilation function creates harmonious interpersonal relationship, and eliminates alienations naturally at the same time (Zhu \& Wang, 2004, p. 24).

\section{Social Aspects}

Radiation function. College culture, as organizational culture, will not only play a role within the organization once it grows mature, but also have an impact on the community through various channels (Gao, 2001, p. 96), "compared with other cultures, its educational and radiation is more stronger" (Zhang \& Chen, 2008, p. 230).

Image-building function. Excellent college culture displays its successful management style, unique college-running characteristics and noble spirit to the public, so as to create a good overall image, establish credibility, and expand its influence (Mao, 2007, p. 38), even "college is also likely to be extended to a brand of the whole university through the brand effect created by its organizational culture" (Li, Shen, Chen, \& Ren, 2013, p. 59).

\section{Education Aspects}

College culture can have an impact on students' professional qualities, moral character, and personality growth (Li, 2012, pp. 22-24). Its spirit, beliefs, habits, and morality permeates among teachers and students as culture atmosphere, which has a strong appeal and driving force to cultivate the students' sentiments, enlighten their mind, and promote their overall development (Zhao, 2010, p. 81). It "is not aimless culture, but permeates a clear educational purpose... leads the students to training targets by the great surrounding force... college culture profoundly affect each student's developing directions, especially their choices of values, moral and lifestyle with subtle force, like constant dropping wears the stone" (Zhang \& Chen, 2008, p. 230).

\section{Construction of College/School/Department Culture}

\section{Construction Content}

Material environment culture is the foundation of college cultural construction, institution culture is the guiding principle of college cultural construction, and spirit culture is the core of the college cultural construction. During material environment cultural construction, teachers and students should be encouraged to 
work together to create special environmental culture. In the institution cultural construction, various management institutions and responsibility institutions should be improved. In spirit cultural construction, attentions should be paid on the refinement of college spirit, and construction of academic culture (Shi, 2012, p. 107). The construction of college/school/department culture should put its emphasis on the teaching style, study style, and the college spirit (Zhao, 2008, p. 22); it should fully condensate college/school/department spirit culture, vigorously promote college/school/department academic culture, and actively foster college/school/department education culture (Li, 2014, p. 25).

\section{Construction Principle}

College/school/department cultural construction should be conducted adhering to the principle of "overarching and guiding," "materialization and enrichment," "specificity and characteristic," "relying on the appropriate platform and window," and "centering around college-running orientation, philosophy, ideas, and goals of college reform and development" (Dong, 2007, pp. 70-71).

\section{Construction Approaches}

College cultural construction needs proceed step by step with designed plan, according to its internal rules: analyzing internal and external cultural environment $\rightarrow$ designing new cultural framework $\rightarrow$ constructing surface culture $\rightarrow$ penetrating and nurturing deep culture conceptions (Gao, 2001, pp. 98-99). From the perspective of the overall university, university-college secondary campus culture management linkage mechanism should be built, leading secondary colleges strengthen links with university and other secondary colleges in the cultural construction, strengthening the guidance and supervision of secondary college cultural construction, and establishing a perfect assessment, appraisal and incentive mechanism (Zhang, 2010, p. 184).

\section{Conclusion}

As a university subculture, college culture is a unique organization culture form created, discovered, and developed from long-term teaching management practice, generally accepted, recognized, and followed by teachers and students of the college/school/department. College culture can be classified into several kinds based on different aspects. College culture has its independence and dissimilarity in the whole university culture system, and plays many important functions. At management aspects, it has directing, cohere, constrain, incentive, coordination, and assimilation function. At social aspects, radiation and image-building function. At education aspects, it can have an impact on students' professional qualities, moral character, and personality growth. To construct college culture effctively, the principle of "overarching and guiding" and "materialization and enrichment" should been adhered to.

\section{References}

Bian, Y. Q. (2008). On the culture construction of college (department) in university (pp. 1-46) (Master thesis, Central China Normal University). (in Chinese)

Bian, Y. Q., \& Yue, K. (2009). On the content system and characteristics of college (department) culture in university. Journal of Higher Correspondence Education (Philosophy and Social Sciences), 22(12), 66-68. (in Chinese)

Cai, X. D. (2006). On the culture construction of the school of management of Beijing Sport University (pp. 1-47) (Master thesis, Beijing Sport University). (in Chinese)

Chen, M., Bi, J. Q., \& Wang, Y. (2010). College (department) culture and its construction of comprehensive university in the perspective of culture in an organization. Higher Education Forum, 26(11), 121-123. (in Chinese) 
Chen, W. J., \& Li, X. M. (2010). A brief analysis on college culture construction of university culture. Journal of Central South University of Forestry \& Technology (Social Science), 4(6), 110-113. (in Chinese)

Dong, X. (2007). Study and practice of cultural construction of secondary college in university: A case study of culture construction of vocational and technical college in Yunnan Nationalities University. China Higher Education Research, 22(5), 70-71. (in Chinese)

Fei, Y. F. (2013). Research on the interaction of construction between the characteristic culture of secondary college and the overall culture of university. Journal of Hubei University of Economics (Humanities and Social Sciences), 10(7), 140-141. (in Chinese)

Gao, P. P. (2001). On the construction of college culture in universities. Tongji University Journal (Social Science Section), 12(4), 94-99. (in Chinese)

Li, B. C. (2012). Research on college culture construction in the perspective of personnel training: A case study on school of intercultural in Jiangxi Normal University (pp. 1-74) (Master thesis, Jiangxi Normal University). (in Chinese)

Li, H., Shen D., Chen, H., \& Ren, P. P. (2013). Research on the organizational culture of college in socialist harmonious campus. Journal of Hunan Academy of Social Sciences, 14(3), 58-61. (in Chinese)

Li, Y. J. (2014). On college (department) cultural construction in university. Journal of Inner Mongolia Normal University (Educational Science), 27(3), 24-26. (in Chinese)

Ma, J. (2013). Practice and thinking of construction of the characteristics culture of the department. Science and Technology Forum, 524(14), 86-87. (in Chinese)

Mao, H. T. (2007). On the construction of college culture. Career, 14(26), 38-39. (in Chinese)

Ouyang, W. F. (2014). Exploration and practice of colleges' culture construction: A case study of materials science and engineering school in Henan Polytechnic University. Journal of Henan Polytechnic University (Social Sciences), 15(2), 245-248. (in Chinese)

Shi, W. B. (2012). Analysis on culture construction of the sub-colleges in universities. Education and Teaching Forum, 12(12), 107-108. (in Chinese)

Tang, H. Y. (2013). On the understanding and practice of the culture construction of the department of the university. Labor Security World, 25(24), 162-163. (in Chinese)

Wang, G. R., \& Wang, S. K. (2006). On the college culture and cultural management of college. Journal of Ningbo University (Educational Science), 28(1), 39-42. (in Chinese)

Yang, Y. Z., \& Guo, J. R. (2013). Incentive effect of organizational culture on the college research secretaries: Taking the case of a "985" comprehensive university. Journal of Higher Education Management, 7(4), 64-71. (in Chinese)

Zhang, W. Y. (2010). The cultural construction of sub-college under the two level management system in university. Journal of Chongqing University of Science and Technology (Social Sciences Edition), 12(17), 183-185. (in Chinese)

Zhang, X. Z., \& Chen, S. (2008). The building and thinking of function of college culture under the background of harmony. China Power Education, 23(9), 230-231. (in Chinese)

Zhao, H. S. (2010). The construction and practice of the characteristic culture of department in higher vocational college with the cultural construction of pharmacy department. Journal of Hunan Environment-Biological Polytechnic College, 16(1), 79-83. (in Chinese)

Zhao, J. (2008). A discussion on the construction of college (department) culture in the construction of campus culture. Education Exploration, 28(12), 21-22. (in Chinese)

Zhao, X. K., Wang, L., \& Zhang, W. D. (2011). Theoretical research on college culture construction in university. Journal of China University of Petroleum (Edition of Social Sciences), 27(6), 105-109. (in Chinese)

Zhu, G. L. (2012). A study on cultural construction of faculties in sight of teaching soft environment. China Educational Technique \& Equipment, 26(27), 47-49. (in Chinese)

Zhu, Y. M., \& Wang, J. P. (2004). The connotation and function of department culture in university. Journal of Changchun University of Technology (Higher Education Study Editions), 25(2), 23-26. (in Chinese) 